\title{
11 Initial Problems of a Children's Home and Experimental School for Refugee Children: The Refugee Children's Homes in Montmorency, France
}

Just four days before Hitler entered the French capital, the last of three hundred refugee children managed to make their escape to southern France from their homes in Montmorency, near Paris, where they have been living for two years.

They came from Germany, Austria, Czechoslovakia and Poland, these children, and most of them had left their native countries without their parents. Many of the fathers were in German concentration camps, some were dead. The parents had, for the most part, no possibility of fleeing because they had no visas for other countries; those fortunates who were on their way to new countries planned to bring their children over when they were settled. About eighty percent of the children were Jewish, the rest were the youngsters of political refugees or of victims of political persecution.

The organization that ran the four houses for the children in France was the French Committee of the OSE Union. These homes, which also gave vocational training, were accepted as an experimental school under the direct supervision of the Academy of Paris. I myself organized these houses and then was their general director.

The educational task that presented itself to us was of a complex nature. We had to keep in mind the previous life led by these refugee children, the special circumstances of their coming to the home and the probable living conditions that awaited them in the future.

(2)

And our task was complicated by the fact that in many cases the children had been without regular instruction for years. They were no longer in the habit of studying systematically. But above all we had to take into consideration the mental shock which the children had suffered as a result of persecution, separation from parents and friends, and emigration.

Some of these young ones had come quite alone. One morning we found a boy of fourteen and a girl of nine standing in the garden; they asked for a place to stay. The only thing the boy had with him was a slip of paper with our address on it. His father had died in a concentration camp. When his mother had heard of his death she had wept and called the Nazis murderers. Consequently she had been sent to the camp herself and the boy had left, heartbroken, their 
home all by himself, taking with him only the little daughter of a neighbor who had to flee without coming home first because the stormtroopers were after him. The children had gotten the address from a minister, crossed the border with the help of a farmer's wife, who had bought them tickets to Paris - and here they were.

Many of the children came to us confidingly with their hopes and thoughts, but there was in them some depression and embarrassment, the mentality of persecution they had tasted in their bitter days in Hitler's Germany.

$$
[. . .]^{281}
$$

The educational principle comes first and its necessities naturally limit the administration as well as the freedom of the adults and children.

Thus, instead of giving the children an illusion of unrestricted freedom, we sought to define with them the limits to their freedom, relying on those principles in which the children themselves saw justice and which made the whole administration not play for them, but reality.

In our home rules only principles were laid down, and with these are descended compliance?

Particular cases and circumstances were not mentioned, since these changed continuously.

Here I should like to give the preamble of

\section{The Constitution of the Children's Homes of the OSE Union}

All the children and adults who live in the children's homes of the OSE Union form a community that directs life in the homes by cooperating democratically in the administration. This community is one part of the great community of all human beings. It is proud to live among the French people and is conscious of belonging to the OSE Union.

"The democratic rights asa well as the duties of the members of the community and the larger ones. The liberties and rights of the members are limited by voluntary subordination to all othe human beings, to the nation in which we live and to the associations to which we belong."

281 Some parts with redundancies to other works by Papanek, where he cites the children's reports about their experiences, have been cut out here to avoid unnecessary repetitions. 
We had wonderful experiences with our co-administration and our disciplinary council. The children approached the problems of co-administration with such dignity and gravity. Much time, of

course, had to be given to explaining the necessity of treating each case of discipline with justice and so making the children understand that certain acts should be punished or censored and that it is necessary to regard certain punishments as just. But the time was not wasted. In our opinion a real educational system must be based on a comprehension on the part of the children that work is a necessity and on their voluntary consent to certain restrictions.

Our children were willing to make the decisions that seemed necessary to us and to execute justified punishment. In fact we had to hold them back from overdoing punishments in their youthful eagerness.

Occasionally we were obliged to interfere in these matters, but we always did so in a way to make the guilty child sure of his guilt. Our effort was to explain to him the meaning of his behavior. Very often it was painful to see the unhappiness of the culprit whom he realized the significance of his "crime". The effect of this educational work was of long duration.

Punishment by grown-ups is in most cases accompanied by the child's sense of being "terrorized" and created inner resistance to what he considers unjust punishment. He excuses himself and makes light of his misconduct. Discussions before the disciplinary council, on the contrary, aided us immeasurably. The chance given the defendant to talk and explain his act, as well as the circumstances of its performance, made him forget to sulk. He came to understand his mistake.

The necessities and complications created by the voluntary cooperation of the children - sometimes troublesome, we admit - were answered with practical success by the method of co-admin-

-istration properly understood by the children. This co-administration was in no vise regarded as merely instructive play, either by the children or by the adults. It was an important part of our educational work. On the one hand it was a scene and the chief means of that - of moral training and character building. And on the other hand it was an inherent part of the deductive Arbeitsunterricht (work-study) school, which seeks to replace superficial knowledge of school subjects by real assimilation of the material and to give the children an opportunity to work according to their individual talents and abilities, with the help of the teacher. 


\section{General Orientation Courses}

In the beginning our school had no definite program in the strict sense of the word. Each groups of children had a daily French lesson, and then there was what we called the "general culture" part of our scheme. All the children there were about a hundred of them at this time living at the Villa Helvetia met together for that lesson. We discussed the events of the day in our little world and in the "world at large". We reviewed them in relation to our personal lives, to our future opportunities. On the arrival of the St. Louis we made the voyage to Cuba and back in our discussions. We explained wy these American islands are called the West Indian Archipelago. This furnished an opportunity to speak of the discovery of American and that period in general, of the country and its inhabitants today. We also discussed the possibilities of going across and the need for learning what would prepare us for emigration. Following these talks our English lessons were instituted.

When the news of the shipwreck of the submarine Squalus ${ }^{282}$ and the efforts made to save its crew were stirring the world, we too spoke at length about it. We estimated the distance between us and the accident, we computed the quantity of oxygen necessary for the rescue. This gave many realization of their lack of knowledge of figures. That week we begun our lessons in mathematics, graded according to the ages of the pupils. We followed the efforts to save the crew as undertaken with the new "diving bell." At this point we entered into the subject of water displacement and hydrostatic pressure. This began for the juniors their object lessons and for the seniors the lessons in physics.

We cut out pictures of the submarine episode from the papers and collected them for a "photo mural." We stressed the courage, the calmness and composure, the tenacity of the shipwrecked men in their submarine prison. We gave admiration to this ideal example of courage and perseverance that had stood up to such difficult circumstances without loss of hope.

Our purpose was to mold character and will-power by citing such examples and fitting them into the framework of humanitarian, moral and democratic education. In the course of our discussions on ethics and real life problems we compared the methods of the military dictatorships, which consider solely their own interests, with the generous notion of the American Government in putting at the disposal of all who needed it the "submariene bell” just successfully done.

282 Later known as USS Sailfish. 


\section{Relationship Between Children and Adults}

It is the relationship that obtains between children and

adults, that plays the greatest part in determining the atmosphere of any educational institution. The children had confidence in our words and our deeds but we had to win this confidence. At first the distrust was very fret. When we first announced that such-and-such would take place on Thursday, the children whispered about on Tuesday, Wednesday, and even Thursday morning, "it's not really going to happen, of course." When we insisted, "yes it will," they answered, "You: - you always say ot will." When the doctor promised this or the other wouldn't hurt nobody believed her, and when we said no exceptions would be made for anybody, everybody was convinced that all the others would be preferred. But we kept our word. We explained the situation carefully in any cases where we were unable to do what we had promised. And so confidence came quite naturally. We never concealed our own insufficiencies; we were the first to admit them and so avoided the mockery and tricks of the youngsters. Our frankness, furthermore, won their respect and awaked in them some chivalry toward the weak points we should never have been able to hide anyway. Very seldom and only in the beginning did the familiar form turn into impudence and arrogance. We hardly had to make any effort to check these indiscretions; the children considered it extremely unfair to abuse our comradeship and they themselves did everything to suppress the impudence of some of their school-mates.

In our comradeship with the children we never lowered ourselves to the child's level. That would have made us ridiculous. We always insisted on the right to lead independent personal lives. It was a community of children and grown-ups; every individual had his right to individual life, all together we forced a respected community.

Here it may be reveling to mention a small fact interesting from an educational point of view. The walls of our houses were never adorned with pencil marks; there were never any designs or drawings even in the lavatories, though we never mentioned the subject to the children. 